Омельяненко Віталій Анатолійович кандидат економічних наук, доцент, докторант Сумський державний педагогічний університет імені А. С. Макаренка, Інститут економіки промисловості НАН України, вул. Роменська, 87, м. Суми, 40002, тел.: (0542) 68-59-02, e-mail: rector@ sspu.edu.ua, https://orcid.org/0000-00030713-1444

Іванюта Вікторія Вікторівна кандидат наук 3 державного управління, старший науковий співробітник кафедри економічної безпеки, публічного управління та адміністування Державного університету «Житомирська політехніка», вул. Чуднівська, 103, Житомир, 10005, тел.: (0412) 24-14-22, e-mail: ztu.edu.ua, https://orcid.org/0000-0002-4037-5590

\title{
УДОСКОНАЛЕННЯ ДЕРЖАВНОГО МОНІТОРИНГУ НАВКОЛИШНЬОГО СЕРЕДОВИЩА $З$ УРАХУВАННЯМ ВИМОГ МІЖНАРОДНИХ ОРГАНІЗАЦІЙ У РАМКАХ СС
}

Анотація. Проведено аналіз ситуації державного моніторингу та виявлення факторів, що заважають здійсненню ефективного державного управління навколишнім середовищем. На цій підставі в галузі досліджень було визначено та сформовано такі групи проблемних аспектів: відсутність довгострокової національної стратегії сталого розвитку; проблема впровадження єдиної термінології, недосконалість чинного законодавства, адаптація національної системи управління до основних європейських принципів; проблема децентралізації влади. Висвітлено міжнародні стандарти та основні принципи природокористування в Європі.

Сьогодні надзвичайно складний і вирішальний період в історії людства безпрецедентний період, що загрожує існуванню цивілізації, посилення багатьох негативних факторів, серед яких: занепад людської моралі; зростання бідності, злочинності; наростаюча агресивність; поширення захворювань (особливо злоякісних пухлин, Covid-2019); деградація природи; ескалація конфлікту між техносферою та біосферою до критичного рівня. Домінування державного підходу, коли заходи 3 охорони навколишнього природного середовища сприймаються не як фактор стабілізації та розвитку державного управління, а навпаки - як перешкода, не дозволяє ефективно державному управлінню в цій галузі. 
Підписання Угоди про асоціацію СС з Україною поставило нові завдання у сфері управління навколишнім середовищем, зокрема його узгодження 3 основними європейськими принципами. Проводячи в контексті європейської інтеграції України, реформа у досліджуваній галузі актуалізує питання розкриття інформації в останньому комплексі проблемних аспектів. Без сумніву, вирішальну роль у розвитку майбутнього суспільства та зв'язку між людськими та природними відносинами має сучасна молодь, тому існує велика потреба в них підвищити рівень екологічної освіти, зрозуміти соціальну та природну присутність, принципи екології та екологічної діяльності, важливі зв’язки людини із навколишнім світом.

Ключові слова: державний моніторинг, державне управління, державна система моніторингу довкілля, навколишнє середовище.

Omelyanenko Vitaliy $\mathrm{PhD}$ (Econ), Associate

Professor, Doctoral Student Sumy State Makarenko Pedagogical University; Industrial Economics Institute of NAS of Ukraine, Romenska St., 87, Sumy, 40002, tel.: (054) 268-59-02, e-mail: rector@sspu.edu.ua https://orcid.org/0000-0003-0713-1444

Ivanyuta Viktoria Viktorivna $\mathrm{PhD}$,Senior Research Fellow, Department of Economic Security, Public Administration and Administration, Zhytomyr Polytechnic State University, Chudnivska St., 103, Zhytomyr, 10005, tel .: (041) 224-14-22, e-mail: ztu.edu.ua, https://orcid.org/0000-0002-4037-5590.

\title{
IMPROVEMENT OF STATE MONITORING OF THE ENVIRONMENT TAKING INTO ACCOUNT THE REQUIREMENTS OF INTERNATIONAL ORGANIZATIONS WITHIN THE EU
}

\begin{abstract}
An analysis of the situation of state monitoring and identification of factors hindering the implementation of effective public environmental management. On this basis, the following groups of problematic aspects were identified and formed in the field of research: the absence of a long-term national strategy for sustainable development; the problem of introduction of uniform terminology, imperfection of the current legislation, adaptation of the national management system to the basic European principles; the problem of decentralization of power. International standards and basic principles of nature management in Europe are covered.

Today is an extremely difficult and decisive period in the history of mankind - an unprecedented period that threatens the existence of civilization, the strengthening of many negative factors, including: the decline of human morality; growing poverty, crime; increasing aggression; spread of diseases (especially malignant tumors, Covid-2019);
\end{abstract}


degradation of nature; escalation of the conflict between the technosphere and the biosphere to a critical level. The dominance of the state approach, when environmental protection measures are perceived not as a factor of stabilization and development of public administration, but on the contrary - as an obstacle, does not allow effective public administration in this area.

The signing of the EU Association Agreement with Ukraine set new challenges in the field of environmental management, in particular its harmonization with the basic European principles. Carrying out in the context of Ukraine's European integration, the reform in the researched area actualizes the issue of information disclosure in the last set of problematic aspects. Undoubtedly, modern youth has a crucial role in the development of the future society and the connection between human and natural relations, so there is a great need to increase the level of environmental education, understand the social and natural presence, principles of ecology and environmental activities, important human connections. with the outside world.

Keywords: state monitoring, public administration, state environmental monitoring system, environment.

Постановка проблеми. Слід зазначити, що стан реалізації заходів, за якими відповідає Міністерство екології та природних ресурсів України, залишається вкрай незадовільним. При середньому рівні реалізації державного плану дій 78,1\% реалізували заходи з охорони навколишнього середовища лише 16\%. 316 запланованих заходів лише 5 були повністю реалізовані, майже $80 \%$ - це 3 : підтримка українських законопроектів про оцінку впливу на навколишнє середовище та стратегічну екологічну оцінку, запровадження системи електронного документообігу [1] . Стан реалізації таких заходів від 40\% до 60\%: розробка та подання в Кабінет Міністрів України проектів законів України "Про основні принципи (стратегію) національної екологічної політики України 2020 року" та "Про відходи", а також перелік проектів постанов Кабінету Міністрів України, «Затвердження Плану дій з управління відходами» та «Затвердження Концепції реформи Державної системи моніторингу навколишнього середовища»; оновлення мети Державного фонду поводження з радіоактивними відходами та створення групи з поводження з радіоактивними відходами [2].

Загалом, заходи, спрямовані на створення ефективної системи контролю за дотриманням природоохоронного законодавства, 3 урахуванням передового досвіду в організації подібних органів в ЄС та концентрації моніторингових та контрольних функцій у галузі навколишнього середовища в межах одного органу. Отже, виходячи з вищесказаного, можна стверджувати, що основною проблемою в минулому є низький рівень виконавчої дисципліни у відповідному міністерстві.

Ще однією проблемою, яку можна віднести до базової, $є$ проблема 
застосування загальноприйнятої термінології, оскільки чинне національне законодавство використовує велику кількість різних понять, починаючи 3 основного терміна "охорона навколишнього середовища", який розкривається в основній інформації. Закон України "Про охорону навколишнього середовища" "Охорона навколишнього середовища", а також взаємозв'язок $з$ визначеннями "раціональне природокористування", "охорона природи", "екологічна політика" тощо [3].

Аналіз останніх досліджень і публікацій. Незважаючи на велику кількість вітчизняних досліджень у галузі охорони навколишнього середовища, лише деякі напрямки були поглиблено вивчені серед науковців, що займаються державним управлінням. Так, були розглянуті питання, пов'язані з розробкою та реалізацією екологічної політики на національному та регіональному рівнях: С. Ашикова, А. Кернична, В. Крук, В. Мариненко, А. Надеженко, О. Настечко, О. Проніната та ін. Такі науковці, як: А. Антонова, В. Демченко, О. Свграфова, Н. О. Лазор, О. Мягченко вивчали напрями державного регулювання використання природних ресурсів. У той же час питання державного управління у сфері довкілля залишається мало дослідженим, особливо в контексті європейських інтеграційних процесів.

Метою статті $\epsilon$ визначення аспектів державного моніторингу охороною навколишнього середовища в Україні з орієнтацією на європейськуінтеграцію.

Виклад основного матеріалу. Експерти Організації Об'єднаних Націй $(\mathrm{OOH})$, екологи з відомих міжнародних та національних екологічних організацій, члени знаменитого Римського клубу на основі наукового аналізу матеріалів про характеристики та тенденції демографічного, соціально-економічного розвитку та наслідки наукового і технологічна революція. а також можливості використання природних ресурсів, а також стан та динаміка забруднення геосфери та біосфери зробили дуже сумні висновки.

Зусилля щодо вдосконалення екологічного моніторингу з урахуванням вимог міжнародних організацій в рамках Європейського Союзу, в першу чергу для координації моніторингу суб'єктів ДМСД, усунення дублювання, оптимізації мереж відповідно до міжнародних стандартів, програм моніторингу, уніфікації та наступності - включає поєднання дії. Вдосконалення технічного та метрологічного забезпечення роботи мереж управління. Слід зазначити, що мережі моніторингу в системі ДСМД України будуються без урахування вимог щодо створення європейської мережі спостережень та накопичення інформації про стан довкілля, включаючи Euro Water Net, EuroAirNet та інші. Тому необхідно переглянути та вдосконалити як неповну мережу моніторингу навколишнього середовища, так i відповідні програми, a також набір показників на їх відповідність міжнародним стандартам та нормам, а також визначити показники. 
Сучасний стан організації контрольних спостережень не повністю відповідає інформаційним потребам ДСМД відповідно до чинних вимог ЄС. Тому необхідно створити просторово оптимізовану мережу моніторингу та програму моніторингу, пристосовану до європейських принципів, стандартів та норм.

В даний час інформація, отримана під час моніторингу довкілля, розміщується у відомчих базах даних, які не завжди структуровані для використання в ДМСД. Крім того, ретроспективна інформація зазвичай накопичується на папері. Така ситуація не дозволяє повною мірою використовувати набори даних для всебічної оцінки екологічного стану навколишнього середовища, взаємодії окремих його компонентів, прогнозувати зміни в екологічному стані екосистем. Підходи та методи оцінки окремих компонентів середовища також суперечливі. У свою чергу, неможливість порівняння даних ускладнює прогнозування несприятливих явищ та вироблення науково обгрунтованих рекомендацій для моделювання розвитку ситуації, передбачення та прийняття оптимальних управлінських рішень у галузі оборони та екологічного та екологічного управління.

Отже, методологічне забезпечення здійснення моніторингу навколишнього середовища, накопичення, зберігання та надання інформації у всіх їі складових має бути консолідованим для всіх суб’єктів ДСМД. Вони повинні базуватися на загальноєвропейських принципах мережевої взаємодії та стандартах, особливо національних, але розроблятись з урахуванням міжнародних принципів та вимог. Надалі методи та прийоми, що застосовуються в системах спостереження ДСМД, повинні забезпечувати відповідний рівень надійності результатів спостереження та відповідати конкретним вимогам інформаційної підтримки для користувачів на різних рівнях - національній, регіональній та соціально-промисловій до загальної. громадськості. Слід підкреслити, що технічна допомога визначає загальний рівень спостережень, тому важливо постійно вдосконалювати пї на основі системного підходу. Цьому сприятиме впровадження системи аналізу технічної підтримки та стану засобів вимірювальної техніки, що використовуються в мережах спостереження ДСМД, та розробка рекомендацій щодо вдосконалення на основі постійного оновлення засобів вимірювальної техніки та лабораторного обладнання відповідно до сучасних вимог. У цьому контексті особливу увагу слід приділити впровадженню багатофункціональних пристроїв, інтеграції вимірювального обладнання, впровадженню автоматизованих станцій спостереження та використанню космічного дистанційного зондування [4].

У галузі метрологічного забезпечення відповідної єдності, точності та надійності результатів спостереження, їх уніфікації, збору, аналізу, узагальнення, єдиної методології подання даних слід досягати в управлінських рішеннях на вищому рівні, ніж громадський. Інструменти для досягнення мети: 
- аналіз методів, програм, показників, що використовуються в ДСМД України та їх гармонізація 3 міжнародними стандартами, їх інтеграція для використання суб'єктів ДСМД;

- вдосконалення методологічних підходів мережі моніторингу, забезпечення необхідного набору спостережень та показників, що відповідають сучасним міжнародним вимогам;

- використання сучасного вимірювального обладнання з відповідним рівнем метрологічних характеристик;

- забезпечення збору, зберігання та передачі даних відповідно до міжнародних вимог та стандартів [4].

Для вирішення всіх цих питань необхідно об’єднати зусилля відомчої служби метрології ДСМД, а також постійно контролювати дотримання міжнародних вимог, включаючи акредитацію відділів контролю та інспекції. та якість. від аналітичного процесу до міжнародних стандартів та правил.

Українські мережі спостереження ДСМД будуються в європейських країнах без урахування методологічних принципів роботи мережі. Тому слід визначити існуючі мережі моніторингу, програми та показники моніторингу, щоб відповідати пріоритетним показникам забруднення, методам їх визначення та, зокрема, міжнародним стандартам та нормам. Стан організації ДСМД не повністю задовольняє інформаційні потреби державних органів та громадськості, тому необхідно вдосконалити як просторову організацію мережі моніторингу, так i програму моніторингу, адаптовану до європейських стандартів та правил. Існують відмінності в переліку контрольованих показників, що використовуються в EuroWaterNet та ДМСД України. У національних програмах спостережень перелік показників набагато ширший за європейські, але вони не забезпечують певних параметрів та показників, що використовуються в мережі EuroWaterNet. Так, за програмою Державної гідрометеорологічної служби в річках та озерах спостерігається до 40 показників, за програмою Державного комітету 3 питань водного господарства - до 30, а за програмою EuroWaterNet лише 17; у морях Державна гідрометеорологічна служба відстежує 20 показників, а за програмою EuroWaterNet лише 16 [5].

Висновки. Підсумовуючи вищевикладене, слід зазначити, що складні проблеми аналізу виявили недоліки у захисті середовища державного управління на сучасному етапі розвитку української держави та корисні для розробки реформи територій $з$ метою вдосконалення ефективність національної системи управління та визначити їі європейські основи.

3 метою вдосконалення системи моніторингу України необхідно перейти до європейських стандартів та норм у створенні мережі моніторингу, відбору, транспортування, зберігання зразків та аналітичної роботи 3 обов'язковим 
міжлабораторним та міждержавним контролем якості аналітичної роботи. Необхідно завершити формування баз даних засобів моніторингу та інформаційної системи 3 урахуванням сучасних геоінформатичних вимог та створити горизонтальні та вертикальні зв'язки між користувачами інформації 3 розвинутими механізмами передачі інформації, правами використання та зобов'язаннями щодо взаємного моніторингу та міжвідомчої координації.

\section{Jimepamypa:}

1. Моніторинг виконання плану дій Уряду за 2016 p. URL : http://cmuplan2016. reforms.in.ua/Bi.

2. Про Стратегію сталого розвитку "Україна - 2020"// Режим доступу [Електронний pecypc]: https://zakon.rada.gov.ua/laws/show/5/2015\#Text

3. Про охорону навколишнього природного середовища [Електронний ресурс] : Закон України від 25.06.1991 р. № 1264-XII. - Режим доступу: http://zakon0.rada.gov.ua/laws/show/ 1264-12.

4. Нова екологія// Режим доступу [Електронний ресурc]: http://www.novaecologia.org/ voecos-296-2.html

5. Strategic Environmental Assessment of Policy, Plan, and Program Proposals: CIDA Handbook. Canadian International Development Agency. - 2004. - 19 p.

6. Декларація про державний суверенітет України : Декларація Верховна Рада УРСР від 16.07.1990 p. № 55-XII. - Режим доступу: http://zakon5.rada.gov.ua/laws/show/55-12.

7. Конституція України [Електронний ресурс] : Закон України від 28.06.1996 р. № 254к/96-BP. - Режим доступу: http://zakon0.rada.gov.ua/laws/show/254\%D0\%BA/96$\% \mathrm{D} 0 \% \mathrm{~B} 2 \% \mathrm{D} 1 \% 80$.

8. Лазор О. Я. Державне управління у сфері реалізації екологічної політики: організаційно-правові засади : монографія / О. Я. Лазор. - Львів : Ліга-Прес, 2003. - 542 с.

9. Мягченко О. П. Основи екології [Електронний ресурс] / О. П. Мягченко. - Режим доступу: http://pidruchniki.ws/17540906/ekologiya/natsionalna_ekologichna

10. Основи екології : підручник для студ. вищ. навч. закл. / [за заг. ред. д-ра екон. наук, проф. Л. Г. Мельника та канд. екон. наук, проф. М. К. Шапочки]. - Суми : Університетська книга, 2017. - 759 с.

\section{References:}

1. Monitorynh vykonannia planu dii Uriadu za 2016 r [Monitoring the implementation of the Government's action plan for 2016]. cmuplan2016.reforms.in.ua. Retrieved from http://cmuplan2016.reforms.in.ua/Bi [in Ukrainian].

2. Ukaz Prezydenta Ukrainy Pro Stratehiiu staloho rozvytku "Ukraina-2020" : vid 12 sichnia 2015 roku, № 5/2015 [Decree of the President of Ukraine On the Sustainable Development Strategy "Ukraine - 2020"from January 12, 2015 № 5/2015]. zakon.rada.gov.ua. Retrieved from https://zakon.rada.gov.ua/laws/show/5/2015\#Text [in Ukrainian].

3. Zakon Ukrainy Pro okhoronu navkolyshnoho pryrodnoho seredovyshcha : vid 25.06.1991, № 1264-XII [Law of Ukraine On the protection of the natural environment from 25.06.1991, № 1264XII]. zakon.rada.gov.ua. Retrieved from http://zakon0.rada.gov.ua/laws/show/1264-12 [in Ukrainian].

4. Sposoby vdoskonalennia monitorynhu navkolyshnoho seredovyshcha $\mathrm{z}$ urakhuvanniam vymoh mizhnarodnykh orhanizatsii $\mathrm{u}$ ramkakh YeS [Ways to improve environmental monitoring taking into account the requirements of international organizations within the EU]. www.novaecologia.org. Retrieved from http://www.novaecologia.org/voecos-296-2.html [in Ukrainian].

5. Strategic Environmental Assessment of Policy, Plan, and Program Proposals: CIDA Handbook. (2004). Canadian International Development Agency [in English]. 
6. Deklaratsiia Verkhovnoi Radu URSR Deklaratsiia pro derzhavnyi suverenitet Ukrainy : vid 16.07.1990 r., № 55-XII [Declaration of the Verkhovna Rada of the Ukrainian SSR Declaration of State Sovereignty of Ukraine from 16.07.1990 № 55-XII]. zakon.rada.gov.ua. Retrieved from http://zakon5.rada.gov.ua/laws/show/55-12 [in Ukrainian].

7. Konstytutsiia Ukrainy : vid 28.06.1996 r., № 254k/96-VR [Constitution of Ukraine : from 28.06.1996, № 254k/96-VR]. zakon.rada.gov.ua. Retrieved from http://zakon0.rada.gov.ua/laws/show/ 254\%D0\%BA/96-\%D0\%B2\%D1\%80 [in Ukrainian].

8. Lazor, O. Ya. (2003). Derzhavne upravlinnia u sferi realizatsii ekolohichnoi polityky: orhanizatsiino-pravovi zasady [Derzhavne upravlinnia u sferi realizatsii ekologichnoi polityky: organizatsiino-pravovi zasady]. Lviv: Liha-Pres [in Ukrainian].

9. Miahchenko, O. P. (2010). Osnovy ekolohii [Fundamentals of ecology]. Kyiv: Tsentr uchbovoi literatury [in Ukrainian].

10. Melnyk, L. H., Shapochka, M. K. (Ed.). (2017). Osnovy ekolohii [Fundamentals of ecology]. Sumy : Universytetska knyha [in Ukrainian]. 